\title{
Duration and severity of Medieval drought in the Lake Tahoe Basin
}

\author{
J.A. Kleppe ${ }^{\mathrm{a}}$, D.S. Brothers ${ }^{\mathrm{b}, *}$, G.M. Kent ${ }^{\mathrm{c}}$, F. Biondi ${ }^{\mathrm{d}}$, S. Jensen ${ }^{\mathrm{e}}$, N.W. Driscoll ${ }^{\mathrm{f}}$ \\ ${ }^{a}$ College of Engineering, University of Nevada, Reno, MS 256, Reno, NV 89557, United States \\ ${ }^{\mathrm{b}}$ Woods Hole Coastal and Marine Science Center, US Geological Survey, 384 Woods Hole Rd, Woods Hole, MA 02543, United States \\ c Seismological Laboratory, University of Nevada, Reno, MS 174, Reno, NV 89557, United States \\ d DendroLab, University of Nevada, Reno, MS 154, Reno, NV 89557, United States \\ e Department of Earth and Planetary Sciences, Northwestern University, 1850 Campus Drive, Evanston, IL 60208, United States \\ ${ }^{\mathrm{f}}$ Scripps Institution of Oceanography, University of California, San Diego, 9500 Gilman Drive, La Jolla, CA 92093, United States
}

\section{A R T I C L E I N F O}

\section{Article history:}

Received 2 February 2011

Received in revised form

22 August 2011

Accepted 24 August 2011

Available online 16 September 2011

\section{Keywords:}

Medieval climatic anomaly

Sidescan sonar

Holocene

Dendrochronology

Drought

Fallen Leaf Lake

\begin{abstract}
A B S T R A C T
Droughts in the western U.S. in the past 200 years are small compared to several megadroughts that occurred during Medieval times. We reconstruct duration and magnitude of extreme droughts in the northern Sierra Nevada from hydroclimatic conditions in Fallen Leaf Lake, California. Stands of submerged trees rooted in situ below the lake surface were imaged with sidescan sonar and radiocarbon analysis yields an age estimate of $\sim 1250 \mathrm{AD}$. Tree-ring records and submerged paleoshoreline geomorphology suggest a Medieval low-stand of Fallen Leaf Lake lasted more than 220 years. Over eighty more trees were found lying on the lake floor at various elevations above the paleoshoreline. Waterbalance calculations suggest annual precipitation was less than $60 \%$ normal from late 10 th century to early 13th century AD. Hence, the lake's shoreline dropped $40-60 \mathrm{~m}$ below its modern elevation. Stands of pre-Medieval trees in this lake and in Lake Tahoe suggest the region experienced severe drought at least every 650-1150 years during the mid- and late-Holocene. These observations quantify paleoprecipitation and recurrence of prolonged drought in the northern Sierra Nevada.
\end{abstract}

Published by Elsevier Ltd.

\section{Introduction}

Evidence for Medieval droughts of duration and magnitude much larger than those in the instrumental record has been reported throughout much of the world, but a particularly robust signal is expressed in the western United States (e.g., Cook et al., 2010 and; Woodhouse et al., 2010). This period of pronounced aridity, the Medieval Climate Anomaly (MCA) of Stine (1994), is best expressed between $\sim 800$ and 1250 AD. Several types of proxy data including tree-ring series, sediment cores, fire reconstructions, and lake-level reconstructions have been used to limit the timing and geographical pattern of the MCA (Graham et al., 2007 and references therein). Yet, quantifying precipitation and basin runoff for such megadroughts with hydrologic models suitable for local or regional water resource management has been difficult.

Tree-ring proxy records of temperature and precipitation during the MCA were first measured along the eastern flank of the Sierra Nevada Range (Graumlich, 1993). Then Stine (1994) documented a series of Medieval droughts from lake-level

\footnotetext{
* Corresponding author. Tel.: +1 5084572293.

E-mail address: dbrothers@usgs.gov (D.S. Brothers).
}

reconstructions and ancient tree stumps in Mono Lake, Walker River, Tenaya Lake and Osgood Swamp. Subsequent studies provided additional proxy records that help limit geographic range and potential causes of the MCA across the Sierras, western Great Basin (Swetnam, 1993; Stine, 1994; Mensing, 2001; Benson et al., 2002; Adams, 2003; Mensing et al., 2004; Kleppe, 2005; Yuan et al., 2006, 2004; Graham et al., 2007; Hallett and Anderson, 2010) and in the Colorado River watershed (Meko et al., 2007). Stine's work in the Mono Basin indicates that prolonged Medieval drought reduced runoff from the central Sierras to Mono Lake. Mono Basin water-balance models (Vorster, 1985) and tree-ring drought-severity indices, show the centennial average precipitation decreased to $75 \%$ and decadal averages decreased to $60 \%$ of twentieth-century values (Graham and Hughes, 2007). Owing to latitudinal variation in Sierran snowfall (Redmond and Koch, 1991; Cayan et al., 1999), the severity and extent of the MCA is uncertain in other regions of the Sierras.

Here we focus on the timing and severity of Medieval drought in the Sierra Nevada and present paleo-precipitation estimates for the Lake Tahoe Basin from 900-1250 AD. We combine dendrochonology, geomorphic analysis, and hydrologic modeling of the Fallen Leaf Lake (FLL) watershed to estimate paleo-precipitation near the headwaters of the Truckee River-Pyramid Lake watershed. 


\section{Background}

The Truckee River/Pyramid Lake watershed covers $7050 \mathrm{~km}^{2}$ of eastern California and northwestern Nevada (Fig. 1). Approximately a third of annual runoff entering Pyramid Lake is from precipitation in the Lake Tahoe Basin (Benson et al., 2002); therefore, large shoreline fluctuations in Pyramid Lake should record changes in precipitation in the headwater streams of Lake Tahoe. Climate proxies (pollen and $\delta^{18} \mathrm{O}$ records) from Pyramid Lake cores reveal increased drought 900-1150 AD (Benson et al., 2002; Mensing et al., 2004), coincident with a period of increased forest-fire frequency 950-1350 AD west of Lake Tahoe (Beaty and Taylor, 2009). Although these studies suggest the MCA led to increased aridity in the Lake Tahoe Basin, they were unable to quantify paleoprecipitation.

Fallen Leaf Lake is a small, but deep ( $>120 \mathrm{~m}$ ) lake, $2.2 \mathrm{~km}$ south of Lake Tahoe at elevation $1945 \mathrm{~m}$ (Fig. 2). It has a surface area of $5.7 \mathrm{~km}^{2}$ and drains into Lake Tahoe through Taylor Creek. A small dam controls the outflow of FLL into Taylor Creek and raises water level $\sim 1.5 \mathrm{~m}$ from its natural sill. Runoff from the Desolation

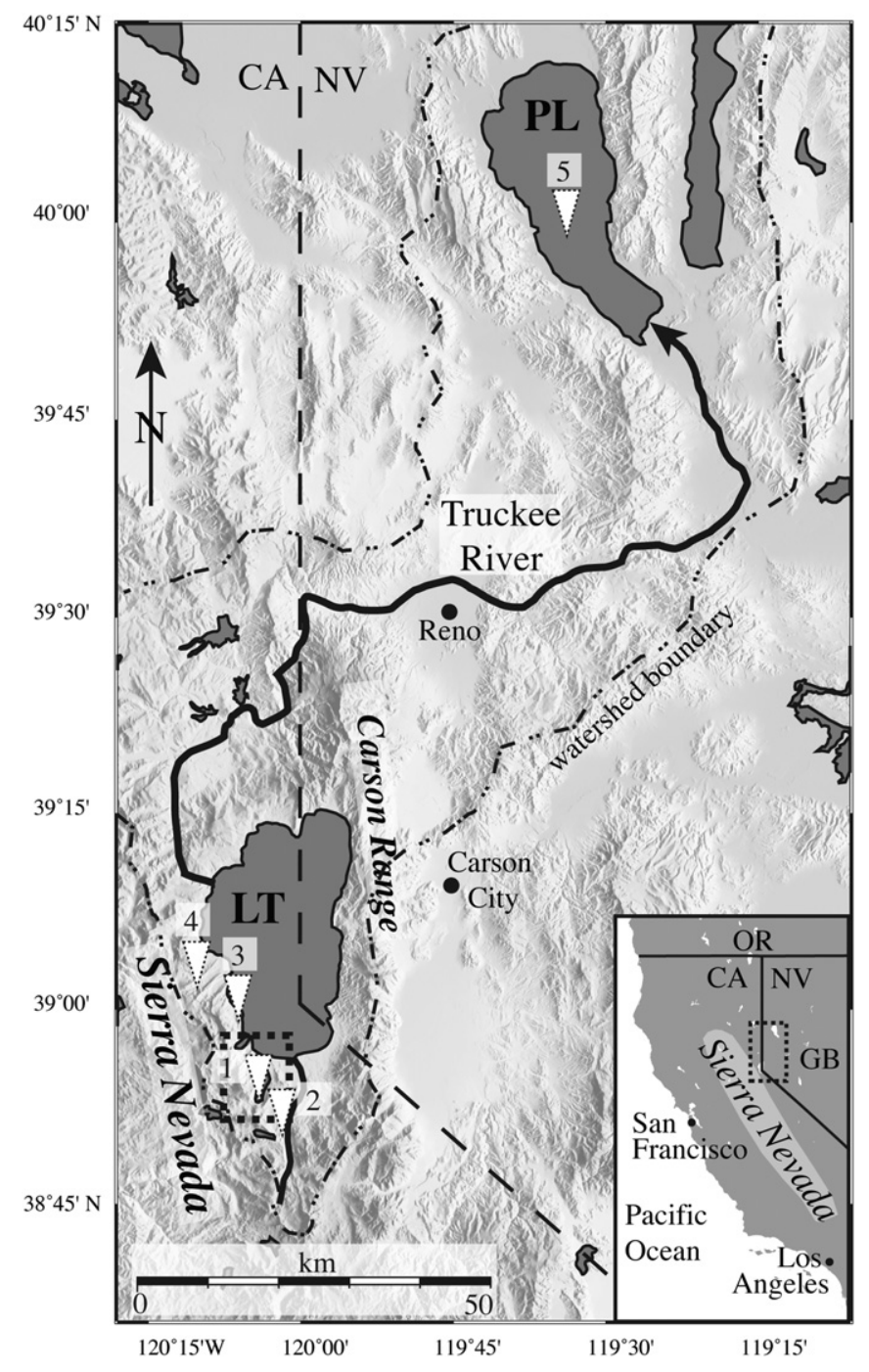

Fig. 1. Map of Truckee River-Pyramid Lake watershed. Inverted triangles (white), show locations of study sites documenting Medieval aridity: (1) Fallen Leaf Lake (this study), (2) Osgood Swamp (Stine, 1994), (3) Rubicon tree stump (Benson et al., 2002), (4) Lilly Pond (Beaty and Taylor, 2009), (5) Pyramid Lake (PL; Benson et al., 2002; Mensing et al., 2004). Bold dashed box south of Lake Tahoe (LT) marks the Fallen Leaf Lake study area. Inset: regional setting.
Wilderness enters the lake via Glen Alpine Creek. The lake fills a narrow glacial valley bounded on both the east and west sides by $>300$-m-high-lateral moraines and separated from Lake Tahoe by several Tioga-aged recessional and terminal moraines (Saucedo et al., 2005; Brothers et al., 2009). The moraines incised by Taylor Creek, expose moderate-to-poorly sorted sand, gravel, and cobbles with occasional well-stratified silty layers (McCaughey, 2005). A broad wetland area near the mouth of Taylor Creek suggests yearround groundwater seepage from FLL to Lake Tahoe. Fallen Leaf Lake's watershed (including the lake) is $\sim 44.65 \mathrm{~km}^{2}$, and is mostly alpine tundra of the Desolation Wildernes sculpted by Pleistocene alpine glaciations (Birkeland, 1964; McCaughey, 2005). Only 30\% of the watershed is forested, most of the basin is floored by thin soils, granodiorite bedrock,and talus. Except for a few small lakes, the rocky watershed provides little groundwater storage. Meanannual precipitation is about $0.4 \mathrm{~m}$ near the outlet dam and may exceed $1.5 \mathrm{~m}$ high in the drainage basin. About $80 \%$ of this precipitation falls as snow in the headwaters of the watershed, where mean April 1 snowpack water content at Lake Lucille (Fig. 2) is $\sim 1.5 \mathrm{~m}$ (Hanes, 1981).

We calculate water balance from hydrologic data for the FLL watershed 1969-1992. Previous studies estimated annual mean precipitation 1969-1992 for FLL and Lake Tahoe watersheds from point measurements in Lake Tahoe Basin (Trask, 2007; Trask and Fogg, 2008). From these data, Trask analyzed the relationship between annual precipitation over the FLL watershed and flow down Taylor Creek. This analysis indicated that FLL is relatively insensitive to climatic variability and shoreline regression occurs only during extremely dry years when precipitation drops below $33 \%$ of normal, a value deemed unrealistic for multi-centennial drought ("normal" precipitation is defined as the mean precipitation over water-years 1969-1992). We present a more comprehensive water-balance model that includes terms for precipitation, stream flow, evaporation, evapotranspiration, stage (lake level), and groundwater flow. With these added terms, a better understanding of FLL's sensitivity and response to changes in precipitation can be achieved.

\section{Methods}

From 2000 to 2009, we completed sidescan sonar, SCUBA, remotely operated vehicle (ROV), and manned submersible missions to characterize lakefloor morphology and locate submerged trees (Figs. 3 and 4). Sidescan data were acquired using an Edgetech 4200 system and GPS navigation to ensure overlapping bottom coverage. The dual frequency (100 and $400 \mathrm{kHz}$ ) system achieves very high resolution in shallow areas, but also images the deeper parts of the lake. The submerged trees are only visible in the $400 \mathrm{kHz}$ data, possibly explaining why the trees were not systematically located earlier using standard $50 \mathrm{kHz}$ fish-finders. Individual sonar swaths were processed and digitally merged by $x$ sonar (Danforth, 1997) into a seamless, geo-referenced mosaic. The corrected $400 \mathrm{kHz}$ data were mosaiced at $0.2-\mathrm{m}$ resolution, with the final images exported as GeoTIFF files. Sidescan mosaics were draped over a bathymetric terrain model (Brothers et al., 2009) to define distribution and depths of lakefloor deposits (Fig. 3). Once located, submerged trees were targeted by ROV, SCUBA, and manned submersible dives. All wood samples acquired by ROV grabs and SCUBA divers were analyzed at the Lawrence Livermore Center for Accelerator Mass Spectrometry and calibrated in OxCal 4.1 (Bronk Ramsey, 2009) using Intcal09 calibration curve (Reimer et al., 2009). A floating crane was used to recover a large downed tree and SCUBA divers sawed off branch samples from upright trees. All samples were analyzed at the University of Nevada Dendrochonology Laboratory by standard methods (Stokes and Smiley, 1996; Biondi et al., 2006). 


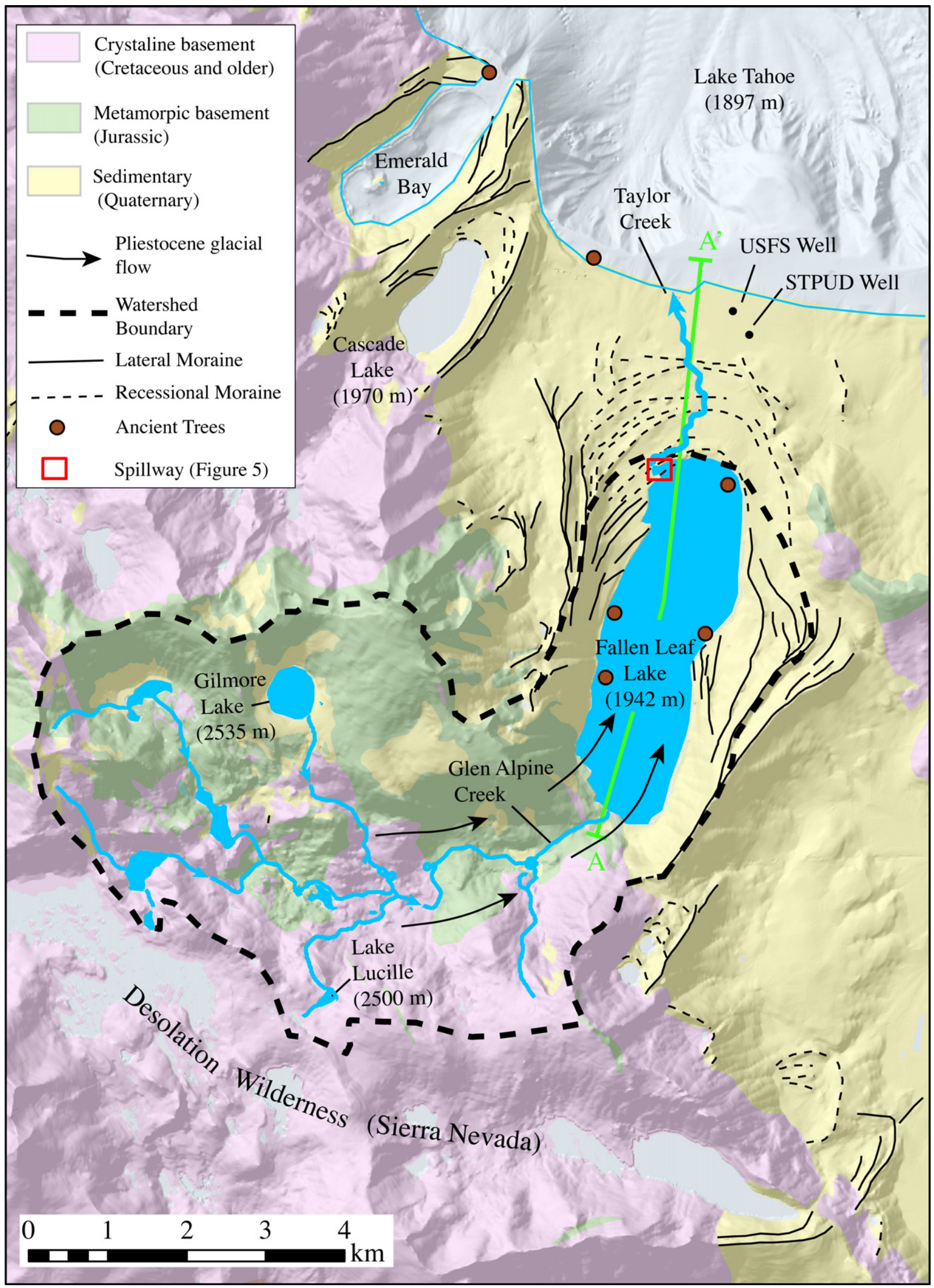

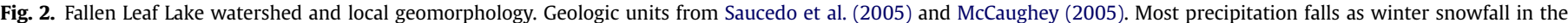

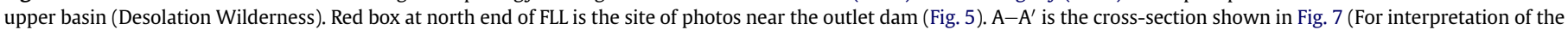
references to colour in this figure legend, the reader is referred to the web version of this article.) 


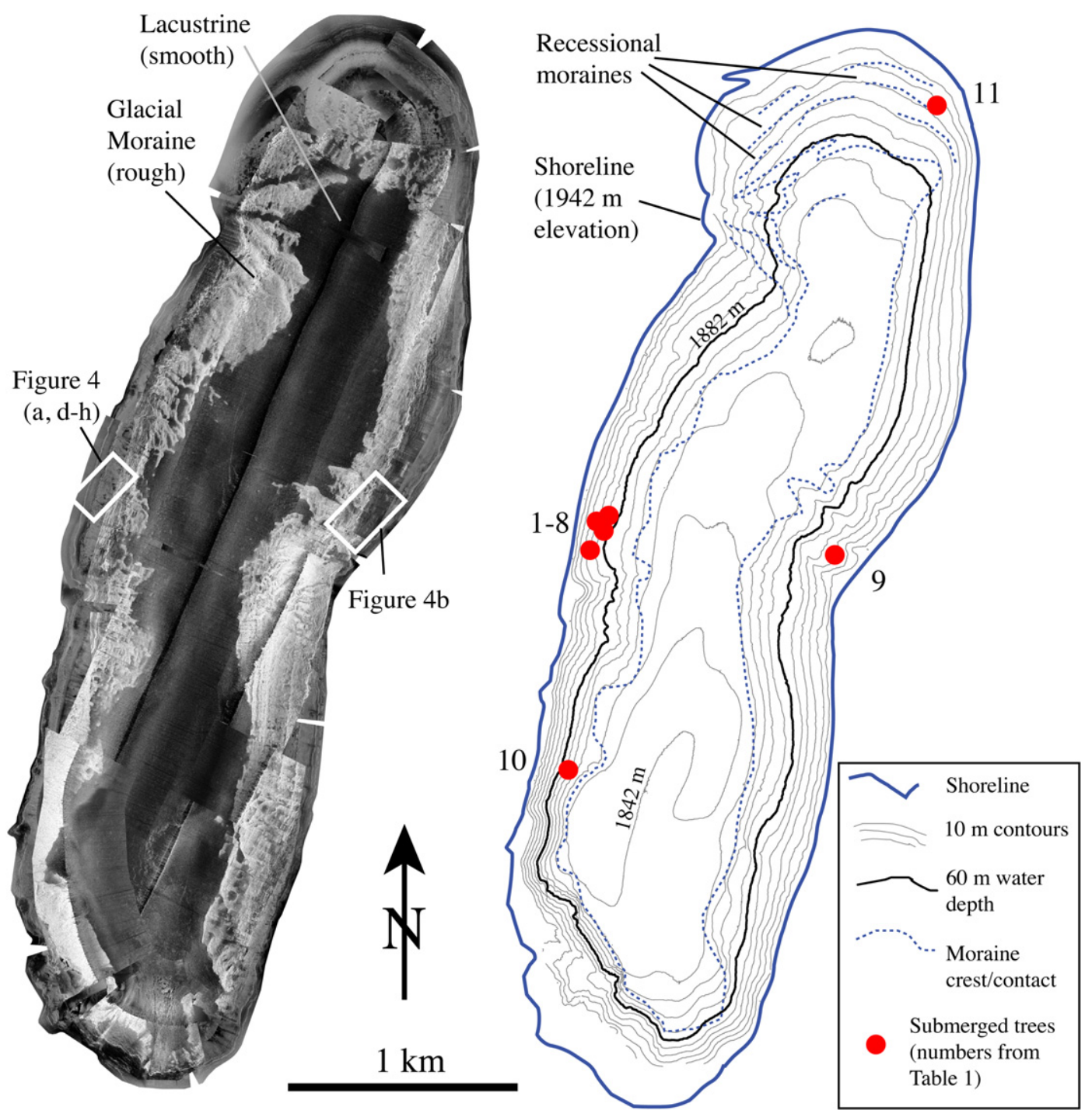

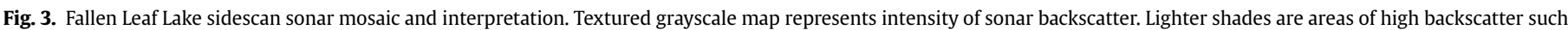

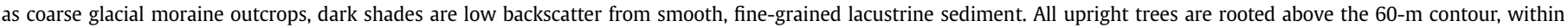
a series of submerged paleoshorelines. White boxes are locations for Fig. 4 images.

We compute a water balance for the FLL watershed that includes terms for evapotranspiration, evaporation, groundwater flow and change in stage:

$P(y)=R_{T}(y)+G W(y)+\Delta S(y)+E_{T}(y)+E(y)$

$y=$ water year over the USGS data period 1969-1992, $P(y)=$ precipitation over watershed (including lake surface), $\Delta S(y)$ $=$ change in stage of FLL, $E_{T}(y)=$ Evapotranspiration over FLL watershed, $E(y)=$ Evaporation from FLL surface, $R_{T}(y)=$ Streamflow down Taylor Creek, $G W(y)=$ Net groundwater flow into and out of the lake

All variables were normalized to the surface area of FLL, following Trask and Fogg (2008), so that flow units are $\mathrm{m} \mathrm{yr}^{-1}$. In other words, the various terms are represented as the amount FLL would go up or down if the flow volume were spread over FLL's surface, making comparisons simple to conceptualize. A detailed study of the Ward Creek watershed provided yearly precipitation estimates for the western margin of the Lake Tahoe basin based on nearby SNOWTEL measurements (Riverson et al., 2005). We derived $P(y)$ based on results in the Ward Creek watershed. Taylor Creek flow data, $R_{T}(y)$, were obtained from a USGS stream gauge
(\#10336626) located $\sim 500 \mathrm{~m}$ downstream from the FLL outlet dam, and $\Delta S(y)$ data were obtained from a USGS lake level gage near the outlet dam (\#10336625). GW(y) is estimated using lakelevel data collected in 2007 and measurements from municipal test wells. Finally, $E_{T}(y)$ and $E(y)$ we derived from a water-balance model and compared to previous estimates in the Lake Tahoe basin (Riverson et al., 2005; Trask, 2007) and other Sierran alpine basins (Armstrong and Stidd, 1967; Leydecker and Melack, 1999; Trask, 2007). Time-series measurements for Snow Course, SNOTEL, $\Delta S(y)$ and $R_{T}(y)$ are publically available.

\section{Results}

Steep, rocky, glacial deposits (high backscatter in Fig. 3) dominate the first-order morphology of the basin, but lacustrine sediment has collected in the deep, mid-section of the lake (low backscatter) and drapes the gentler slopes in the northern lake (Fig. 3). Several moraines constitute the hummocky bathymetry of the northern third of the lake and the greatest depths occur in the southern lake adjacent to a steep escarpment that coincides with the West Tahoe-Dollar Point Fault (Brothers et al., 2009). 

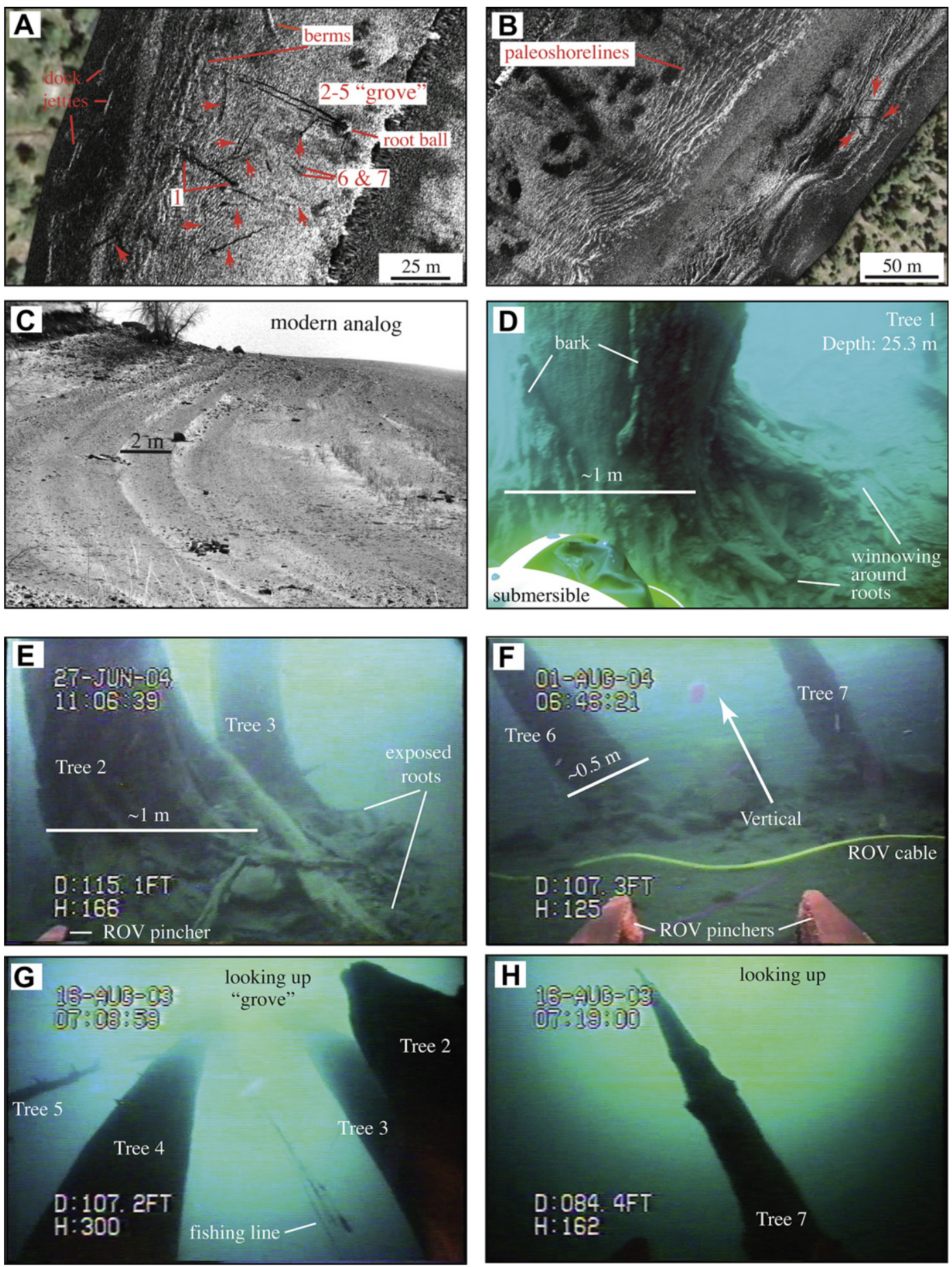

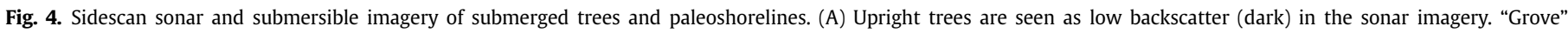

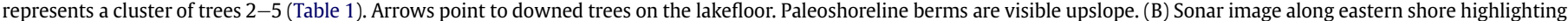

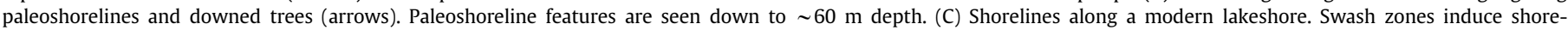

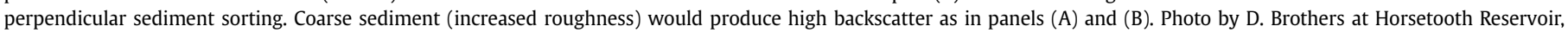
Fort Collins, CO. (D) Photo of Tree \#1 from a submersible. (E-H) Still frames from ROV video showing trees 2-7.

At least 80 trees were identified on the lake floor; all trees observed in sidescan imagery are above the 60-m depth contour (Figs. 3 and 4). At least eleven large, upright trees remain rooted between 14 and $36 \mathrm{~m}$ below modern lake surface. Each exhibits very low backscatter likely as a result of their convex surface, low roughness, and waterlogged condition. Some exceed $30 \mathrm{~m}$ tall and $1.1 \mathrm{~m}$ diameter (Kleppe, 2005). Root structures studied during submersible dives reveal the upright trees grew in situ and on some trees, bark remains near the base of the trunk (Fig. 4D-H; Supplementary Video 1). Sidescan and sub-bottom seismic data (Brothers et al., 2009) show relatively undisturbed paleoshoreline morphology around the lake margin (Fig. 4A,B). There is no stratigraphic or geomorphic evidence for widespread slumps, slides, or faults that could have transported the trees down into the lake. Alternating bands of high and low backscatter that parallel the modern shoreline (Fig. 4B) are interpreted as submerged 
paleoshoreline features. Because shoreface relief is low in ROV video footage, the backscatter banding probably reflects roughness variations between sequential swash zone deposits. Fig. 4D shows a modern analog. The paleoshoreline features can be traced around the lake, the deepest imaged about $60 \mathrm{~m}$ down, or $1882 \mathrm{~m}$ elevation.

Supplementary video related to this article can be found at doi: 10.1016/j.quascirev.2011.08.015.

Several ancient, submerged trees have been radiocarbon dated with the full range of dates falling between $1607 \mathrm{BC}$ and $1292 \mathrm{AD}$ (Table 1). Undated trees 3 and 5 stand upright in a grove (Fig. 4) that also includes trees 1,2 and 4. Tree death-dates have poor evidence for clustering: trees 4 and 11 died $\sim 1225 \mathrm{AD}$, Tree 1 died $\sim 1170$ $\mathrm{AD}$, and Tree 9 , which was not upright, died around $1080 \mathrm{AD}$. The two radiocarbon dates for Tree 2 split between the first and second group and error bars overlap between them. Several older (preMedieval), upright rooted trees are in the lake (trees 6, 7, 8; in Table 1). Bark and branches have fallen from the trunks of the older trees and the visual appearance of the wood looks far more "weathered" than the Medieval trees. Tree 10 was found (by the ROV) on its side in deeper waters with several small rocks and cobbles on its trunk and branches. Wood samples from tree 10 appear to overlap in age with trees 6 and 7 (372 BC - 335 AD) and Tree 8 dates back to 1405-1607 BC.

Two branch samples from Tree 1 (Supplementary Video 1) and a large section of trunk ( $>10 \mathrm{~m}$ ) from Tree 9 were recovered and analyzed at the University of Nevada DendroLab (Kleppe, 2005; Biondi et al., 2006). The tree-ring analysis was conducted to obtain calendar dates and continuous ring-width series. A reference chronology for 543-2003 AD was developed with cores from western juniper (Juniperus occidentalis) on the moraine just west of the lake (Biondi et al., 2006). The master chronology included 22 series from 16 trees that correlate well with all other tree-ring chronologies available for the western USA. It is clear that the western juniper master chronology is closely related to other Sierra Nevada sites (Biondi et al., 2006). Ring-width series of submerged trees were compared to the master chronology. Anatomical features of the submerged samples indicate a pine species. Tree 9 was radiocarbon dated to 996-1165 AD and contained 200 growth rings, but the ring widths did not contain the variation or sensitivity to known climatic events, therefore it could not be crossdated to the master chronology. A sequence of 69 rings in a branch of Tree 1 (dated to 1055-1292 AD) yielded a 0.7 correlation coefficient to the master chronology for the period $A D$ 1085-1134, which suggests the 1080 AD center-age for the radiocarbon date is too young.
To understand the hydrologic properties of Fallen Leaf Lake, the magnitude of groundwater discharge, $G W(y)$, was quantified using two comparative analyses. The first estimate is based on measurements taken in late November and early December 2007, near the end of a very dry year where about $60 \%$ normal precipitation fell on the Fallen Leaf Basin. Inflow from Glen Alpine Creek and the outflow down Taylor Creek were both zero, and only minute precipitation fell during the measurement period, meaning that $E_{T}=0$. An automated weather station 4-m above the lake surface recorded air temperature, barometric pressure, relative humidity, wind speed and direction, and precipitation during this measurement period. Lake level was recorded by an automated USFS lake level system in a stilling well; the gauge's resolution is $0.305 \mathrm{~mm}$ and operated during the entire measurement period. During the measurement period, the relative humidity was over $90 \%$, average air temperature about $8{ }^{\circ} \mathrm{C}$ and winds were calm, suggesting evaporation was low. Meanwhile lake level dropped an average $7.9 \mathrm{~mm}$ day $^{-1}$, exposing an expanse along the gradually sloping north shoreline, and numerous tree stumps cut and drowned $\sim 75$ years ago during construction of the dam (Fig. 5). We assume an upper bound on evaporation of $1.5 \mathrm{~mm}^{-1}{ }^{-1}$ (Trask, 2007), which yields a drop of $6.4 \mathrm{~mm} \mathrm{day}^{-1}$. This equates to a loss of $2.40 \mathrm{~m} \mathrm{yr}^{-1}$ over the surface of FLL $\left(1.37 \times 10^{7} \mathrm{~m}^{3} \mathrm{yr}^{-1}\right.$ in standard units) due to groundwater seepage.

Second, subsurface hydraulic properties between FLL and Lake Tahoe were estimated based on 26 measurements from South Tahoe Public Utility District (STPUD) and US Forest Service wells (Fig. 3; data and calculations courtesy of Ivo Bergsohn, STPUD). A simple flownet was constructed by assuming a homogeneous (single-layer) aquifer between the lakes, and the spillway elevations of FLL and Lake Tahoe are assumed to form constant head boundaries (Bergsohn, 2011). The cross sectional area of the flow $\left(734,186 \mathrm{~m}^{2}\right)$ was constrained by gravity modeling of the depth to impermeable bedrock (Pearson, 1999) and subterranean flow can occur below the level of Tahoe's shoreline due to the higher hydraulic head of FLL. The average hydraulic conductivity was estimated at $\sim 10 \mathrm{~m} \mathrm{day}^{-1}$, slightly larger than typical glacial till (Freeze and Cherry, 1972) with a hydraulic gradient estimated to be 0.016 . It follows that hydraulic conductivity multiplied by the crosssectional area and the hydraulic gradient provides an estimated yearly groundwater discharge of $2.46 \mathrm{~m} \mathrm{yr}^{-1}$ over the surface of FLL $\left(1.4 \times 10^{7} \mathrm{~m}^{3} \mathrm{yr}^{-1}\right)$.

Next, a water-balance calculation combined results from Riverson et al. (2005), Trask (2007) and Hanes (1981) to examine the mean annual evaporation and evapotranspiration. Riverson

Table 1

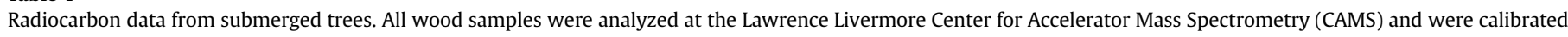

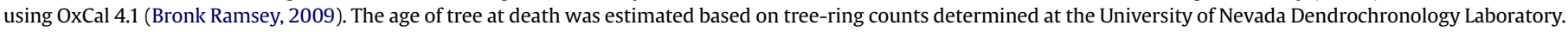

\begin{tabular}{|c|c|c|c|c|c|c|c|c|}
\hline Tree no. & CAMS no. & $\begin{array}{l}\text { Depth below } \\
\text { surface }(\mathrm{m})\end{array}$ & $\begin{array}{l}\text { Elevation of } \\
\text { base }(\mathrm{m})\end{array}$ & $\begin{array}{l}\text { Height of } \\
\text { tree }(\mathrm{m})\end{array}$ & $\begin{array}{l}{ }^{14} \text { C Age } \\
\text { (yrs B.P.) }\end{array}$ & $\begin{array}{l}\text { Cal age } \\
\text { (yrs B.P.) }\end{array}$ & $\begin{array}{l}\text { Date of Death } \\
\text { (Cal yrs AD) }\end{array}$ & $\begin{array}{l}\text { Age of tree } \\
\text { at death }\end{array}$ \\
\hline 1 & 87442 & 25.3 & 1918.2 & 20.8 & $790 \pm 50$ & $892-658$ & $1058-1292 \mathrm{AD}$ & 220 \\
\hline 1 & 87443 & 25.3 & 1918.2 & 20.8 & $825 \pm 40$ & $895-675$ & $1055-1275 \mathrm{AD}$ & 220 \\
\hline 2 & 87444 & 36 & 1907.8 & 26.7 & $810 \pm 35$ & $784-677$ & $1166-1273 \mathrm{AD}$ & 200 \\
\hline 2 & 87445 & 36 & 1907.8 & 26.7 & $830 \pm 40$ & 899-676 & $1051-1274 \mathrm{AD}$ & 201 \\
\hline 3 & Undated & 35.8 & 1907.7 & 5.5 & Undated & Undated & Undated & - \\
\hline 4 & 87446 & 35.4 & 1908.1 & 30.7 & $800 \pm 35$ & $775-673$ & $1175-1277 \mathrm{AD}$ & 200 \\
\hline 4 & 87447 & 35.4 & 1908.1 & 30.7 & $810 \pm 35$ & $784-677$ & $1166-1273 \mathrm{AD}$ & 200 \\
\hline 5 & Undated & 36 & 1907 & 10.5 & Undated & Undated & Undated & - \\
\hline 6 & 99483 & 34.1 & 1908.1 & 6.1 & $1805 \pm 40$ & $1861-1615$ & $89-335$ AD & - \\
\hline 6 & 109733 & 34.1 & 1908.1 & 6.1 & $1815 \pm 45$ & $1868-1619$ & $82-331$ AD & - \\
\hline 7 & 109732 & 33.2 & 1910.3 & 9.6 & $1930 \pm 35$ & $1988-1815$ & $38 \mathrm{BC}-135 \mathrm{AD}$ & - \\
\hline 8 & 109734 & 30.5 & 1913 & 5 & $3230 \pm 35$ & $3557-3379$ & 1607 BC -1429 BC & - \\
\hline 9 & 99484 & 36.9 & 1906.7 & $\mathrm{~N} / \mathrm{A}$ & $960 \pm 40$ & $954-785$ & $996-1165$ AD & 200 \\
\hline 10 & 99481 & $\mathrm{~N} / \mathrm{A}$ & $\mathrm{N} / \mathrm{A}$ & $\mathrm{N} / \mathrm{A}$ & $2175 \pm 40$ & $2324-2060$ & $374 \mathrm{BC}-110 \mathrm{BC}$ & - \\
\hline 11 & 109889 & 14.3 & 1929 & 12.3 & $780 \pm 40$ & $772-666$ & $1178-1284 \mathrm{AD}$ & - \\
\hline
\end{tabular}



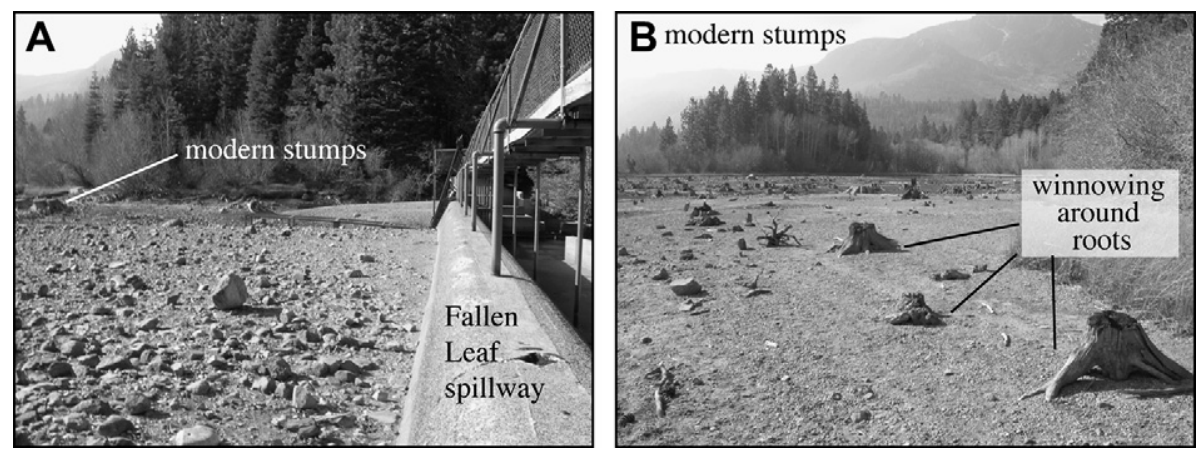

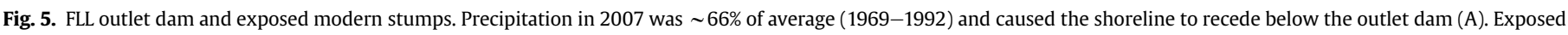

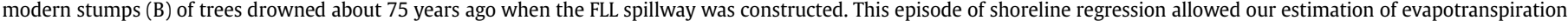

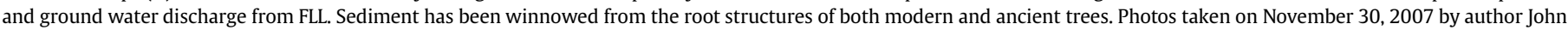
Kleppe.

et al found a total of $1.73 \mathrm{~m}$ of annual precipitation over the Ward Creek watershed, which provides a minimum estimate on the FLL watershed because the precipitation in the Desolation Wilderness (e.g., at Lake Lucille) is consistently higher than other sites on the western margin of the Lake Tahoe Basin. We set $P(y)=1.73 \mathrm{~m} \mathrm{yr}^{-1}$, or $13.55 \mathrm{~m} \mathrm{yr}^{-1}$ normalized to the surface of FLL. Terms for mean annual flow down Taylor Creek $\left(R_{T}(y)=6.73 \mathrm{~m} \mathrm{yr}^{-1}\right)$, change in stage $\left(\ddot{A} S(y)=0.00 \mathrm{~m} \mathrm{yr}^{-1}\right.$ ) and groundwater discharge $G W(y)$ are substituted into Equation (1) to solve $E_{T}(y)+E(y)=4.42 \mathrm{~m} \mathrm{yr}^{-1}$ over the surface of FLL. The net groundwater discharge from Fallen Leaf Lake through the end moraine and into Lake Tahoe is $~ 18 \%$ of the mean-annual precipitation entering the watershed and evaporation off FLL and evapotranspiration off the watershed combine for $\sim 33 \%$ of the annual precipitatation.

Next, we created a linear equation to represent $\left(E_{T}(y)+E(y)\right)$ in Equation (1) and assumed groundwater inflow to FLL is included in annual precipitation estimate. The term $\left(E_{T}(y)+E(y)\right)$ was assumed to relate linearly to normalized precipitation, a reasonable assumption given the well-behaved linear relationships between the precipitation and the flow down Taylor Creek (blue line Fig. 6). The variables in the linear equation were determined by varying $x$ from very wet $(x=1.8)$ to very dry $(x=0.2)$. This procedure resulted the following expression:

$\left(E_{T}(y)+E(y)\right)=3.36 x-1.06$

Trask and Fogg (2008) derived $R_{T}(y)=10.19 x-3.46$ as the bestfit linear regression between precipitation $(x)$ and flow down Taylor Creek, where $x$ represents each precipitation value divided by the mean of 1969-1992. For instance, at normal precipitation (i.e., the mean between 1969 and 1992), $x=1$ and $R_{T}(y)=6.73 \mathrm{~m} \mathrm{yr}^{-1}$ over the surface of FLL. The linear fit in Fig. 6 (blue line) illustrates that the watershed is well behaved and high precipitation corresponds to high flow down Taylor Creek, low precipitation to low flow. A complete representation of the FLL basin yield $(F L Y)$ is found by including additional terms:

$F L Y(y)=R_{T}(y)-\Delta G W(y)+\Delta S(y)$

The mean value of $\Delta S$ during WY 1971-1992 was effectively zero (measured from USGS gauge \#10336625), likely because lake level and Taylor Creek outflow each year were controlled by the US Forrest Service (USFS) at the outlet dam in order to satisfy an annual lake-level template. $\ddot{A} G W=G W_{\text {in }}-G W_{\text {out }}$, but $G W_{\text {in }}$ is set to be zero. Therefore, to solve for FLL Equation (3), the expression for Taylor Creek flow is shifted by $G W_{\text {out }}$, or $2.40 \mathrm{~m} \mathrm{yr}^{-1}$ (red line in Fig. 6):

$F L Y(y)=10.19 x-5.86$
The result shows that FLL's shoreline will drop once $P(y)-[E t(y)+E(y)]<G W_{\text {out }}$, or when precipitation drops below $\sim 60 \%$ normal (Fig. 6, red line). Between depth contours of 0 and $40 \mathrm{~m}$ and between contours 0 and $60 \mathrm{~m}$, FLL contains approximately $1.92 \times 10^{8} \mathrm{~m}^{3}$ and $2.66 \times 10^{8} \mathrm{~m}^{3}$ of water, or $33.8 \mathrm{~m}$ and $56.6 \mathrm{~m}$ when normalized to the surface area of FLL. If we assume groundwater flux remains constant and an average annual precipitation at $40 \%$ of normal, Fallen Leaf's shoreline would drop $40 \mathrm{~m}$ in less than 20 years and $60 \mathrm{~m}$ in less than 30 years. Groundwater flux is expected to decrease linearly as a function of hydraulic gradient between Fallen Leaf and Lake Tahoe where evaporation and evapotranspiration soon become the main water loss. In any case, we expect Fallen Leaf's shoreline to require less than 50 years to reach the level of the Medieval tree roots.

\section{Discussion}

When all terms in the water-balance calculations are included it becomes clear that groundwater flow from Fallen Leaf Lake to Lake Tahoe provides a mechanism for rapid shoreline fluctuation during

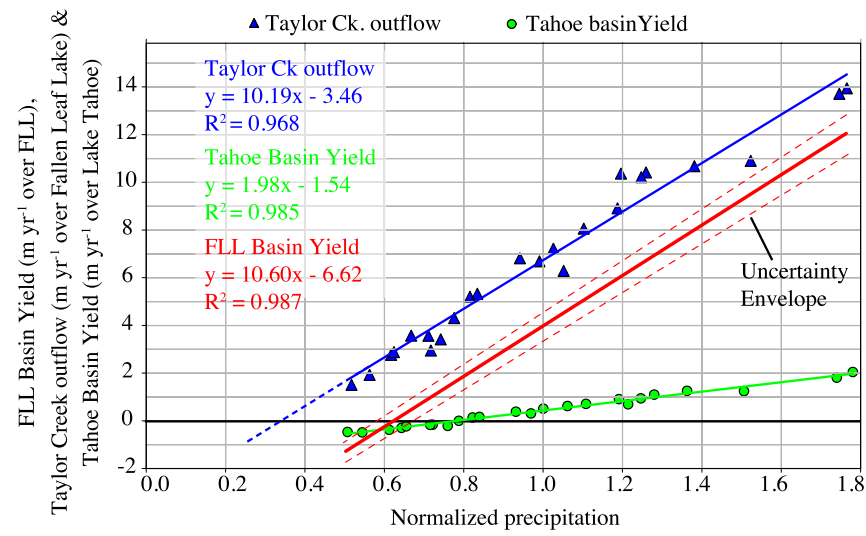

Fig. 6. Taylor Creek outflow, Fallen Leaf Basin annual water yield and Tahoe Basin annual water yield versus normalized precipitation for water-years 1969-1992 (modified from Trask and Fogg, 2008). Precipitation value 1.0 is considered "normal" and represents the mean precipitation over Fallen Leafs (blue) and Tahoe's (green) basins normalized by the surface area of each lake. Negative yield values represent a net drop in lake level for a given year. Blue line represents relation between normalized precipitation and flow down Taylor Creek. Taylor Creek flow is only one component of total FLL basin yield. Red line represents FLL basin yield accounting for net groundwater flow and changes in the lake level. FLL basin yield goes negative at $\sim 0.60$ of normal precipitation (For interpretation of the references to colour in this figure legend, the reader is referred to the web version of this article.) 
extreme droughts. Normal precipitation allows Fallen Leaf to maintain its hydraulic head over Lake Tahoe while supplying flow down Taylor Creek and groundwater flow through the end moraine (Fig. 6). A simple comparison between the ratio of watershed area to lake area for Lake Tahoe $(\sim 1.6)$ and FLL $(\sim 7.6)$ might suggest that FLL is less affected by drought than Lake Tahoe (Freeze and Cherry, 1972; Trask and Fogg, 2008). But discharge to Taylor Creek as a percentage of watershed precipitation (i.e., watershed efficiency) is lowered dramatically because of the groundwater seepage, making the Fallen Leaf watershed less efficient than Lake Tahoe. Despite significant scatter in the data (Trask, 2007) illustrates how Lake Tahoe watershed, during onset of a drought, changes from runoff-dominated inflow to inflow sourced primarily from precipitation directly on the lake surface. Evapotranspiration becomes negligible and Lake Tahoe becomes more efficient. In contrast, Fallen Leaf's watershed becomes less efficient during drought than during wet years and its shoreline will drop faster than Lake Tahoe's, making it more climatically sensitive. Small, moraine-bounded lakes, like Fallen Leaf higher in the watershed are more sensitive to hydroclimatic change and may contain highfidelity records of pre-historic precipitation.

Water-balance models can be subject to large uncertainties, particularly components of evapotranspiration and ground water flow. In 2010 a US Fish and Wildlife Service diver observed a small underwater spring on the lake floor near the trace of the West Tahoe Fault (Phil Caterino personal communication), otherwise we have no constraint on groundwater inflow. We expect groundwater inflow to represent a component of the annual precipitation that reaches FLL and therefore do not assign and indpendent term in the water balance. We provide a lower-bound on the sum of evapotranspiration and evaporation (up to $4.4 \mathrm{~m} \mathrm{yr}^{-1}$ over FLL). Assuming FLL has the same mean annual evaporation as Lake Tahoe: $E(y)=0.91 \mathrm{~m} \mathrm{yr}^{-1}$ (Trask, 2007), evapotranspirtation would be $3.51 \mathrm{~m} \mathrm{yr}^{-1}\left(0.45 \mathrm{~m} \mathrm{yr}^{-1}\right.$ over the watershed). This estimate is less than other sites in the Lake Tahoe basin $\left(\sim 1 \mathrm{~m} \mathrm{yr}^{-1}\right.$;Trask, 2007; Riverson et al., 2005) and other alpine watersheds of the Sierra (Armstrong and Stidd, 1967; Leydecker and Melack, 1999; Trask, 2007). Snowfall in the Desolation Wilderness is anomalously high at elevations over $8000^{\prime}$. Snow Course measurements at Lake Lucille, which were not included in the Ward Creek precipitation model (Riverson et al., 2005), show more than twice the snow water content on April 1 than other sites around the Tahoe basin at the same elevation. Approximately $60 \%$ of the annual April 1 snowpack in the FLL watershed occurs above $8000^{\prime}$, meaning the mean annual precipitation may be a maximum of $30 \%$ higher than the value used in our water-balance $\left(2.33 \mathrm{~m} \mathrm{yr}^{-1}\right.$ over the watershed). This increases evapotranspiration to $1.00 \mathrm{~m} \mathrm{yr}^{-1}$ over the watershed, closer to previous estimates (Riverson et al., 2005; Trask, 2007).

The FLL watershed is only $30 \%$ forested, contains steep slopes, is dominated by exposed granitic and metamorphic bedrock and contains diminutive sedimentary cover (Fig. 2) leaving little storage for groundwater. The watershed produces rapid runoff during the late spring and early summer. These factors combined would suggest the watershed has low evapotranspiration relative to Ward Creek, which contains significantly higher forrest cover. One might anticipate higher evapotranspiration rates during the MCA due to warmer temperatures. Higher evapotranspiration would cause the FLL shoreline to be more sensitive to decreased precipitation. However, due to fire suppression practices the density of modern forests is exponentially greater than that of pre-historic forests (Taylor and Beaty, 2005; Swetnam et al., 2009), which would partially counteract the effect of temperature increase. We speculate that evapotranspiration in the FLL watershed during the MCA may not have been significantly different than today. In summary, the modern evapotranspiration is between 0.45 and $1.05 \mathrm{~m} \mathrm{yr}^{-1}$, or $18-45 \%$ of the total precipitation.

As with Mono Lake and Lake Tenaya (Stine, 1994), an extended drought with low runoff changing rapidly to a wet period with high runoff is a plausible explanation for the drowned trees in Fallen Leaf Lake. The oldest and youngest Medieval trees span 996-1292 $\mathrm{AD}$ (including uncertainty); subtracting the 200 years of growth from tree rings places the beginning of the MCA at $\sim 800 \mathrm{AD}$. And so, in the early 9th or latest 8th Century AD, average yearly precipitation appears to have dropped below $60 \%$ normal. Fallen Leaf Lake would drop relatively quickly based on the rate of groundwater discharge. In only a few decades it dropped to the same elevation of Lake Tahoe before stabilizing by groundwater exchange between the two lakes (Fig. 8). Because trees grew for at least 220 years, seasonal fluctuations in the Medieval shoreline must have been confined to a depth range between $\sim 40-60 \mathrm{~m}$ below the present shoreline. This also suggests average precipitation during this period was less than $\sim 60 \%$ of normal. Precipitation at $60 \%$ of normal causes lake still stands as it is roughly equal to evaporation and groundwater flow out of FLL. During a drought the most sensitive trees tend to perish and reconstructions may then have to be based on records from larger tress that were less affected by variable precipitation, which could underestimate drought severity. We find $60 \%$ of normal, the lower bound on precipitation in Central California during the MCA (Graham and Hughes, 2007), is actually close to the upper-bound on precipitation in the Fallen Leaf watershed. Flooding in the Carson Sink sometime between 1035 and 1298 due to increased discharge from the Walker and Humboldt rivers (Adams, 2003) coincides with the drowning age of the trees in FLL (Table 1; Fig. 8).

Unlike previous reports of Medieval drought in the Sierras (Stine, 1994; Benson et al., 2002; Cook et al., 2004; Graham and Hughes, 2007), we do not observe evidence for more than one distinct episode of tree growth in Fallen Leaf Lake. The calibrated radiocarbon dates appear to separate into two or three groupings (Fig. 8), but all dates have overlapping error bars. The tree ages at death from ring-counts and the dendrochonology for Tree 1, each suggest that tree deaths were not separated into distinct intervals. Dated stumps in Osgood Swamp (Stine, 1994) and near Rubicon Point in Lake Tahoe (Benson et al., 2002) are recalibrated using OxCal 4.1 to $994-1216 \mathrm{AD}$ and $680-881 \mathrm{AD}$, respectively. The stump near Rubicon Point is rooted at elevation $1893 \mathrm{~m}$, suggesting Lake Tahoe's shoreline was also lower at about the same time (Benson et al., 2002). If we assume the Rubicon tree grew a few meters above Lake Tahoe's shoreline, the Medieval shorelines in FLL and Lake Tahoe were roughly about the same elevation (Fig. 7). Additional stump dates are required in Lake Tahoe, but the two lakes may have dropped to about the same level for several centuries, allowing trees to grow above their lowered shorelines. When precipitation increased, Fallen Leaf Lake rose tens of meters

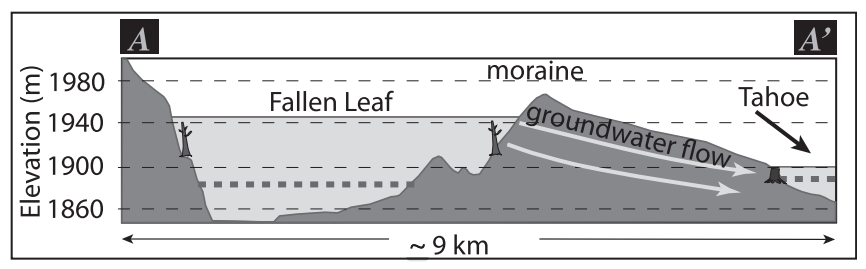

Fig. 7. Topographic profile and hydrogeologic schematic. $A-A^{\prime}$ is the cross-section on Fig. 2. Ancient trees in FLL are rooted at $\sim 36 \mathrm{~m}$ below the surface (elevation $\sim 1906 \mathrm{~m}$ ). Submerged paleoshorelines are observed down to $\sim 60 \mathrm{~m}$ below the surface, approximately the elevation of a Medieval stump offshore Rubicon Point in Lake Tahoe (Fig. 1; Benson et al., 2002). Differential hydraulic head between FLL and Lake Tahoe allows ground water flow through the end moraine. 


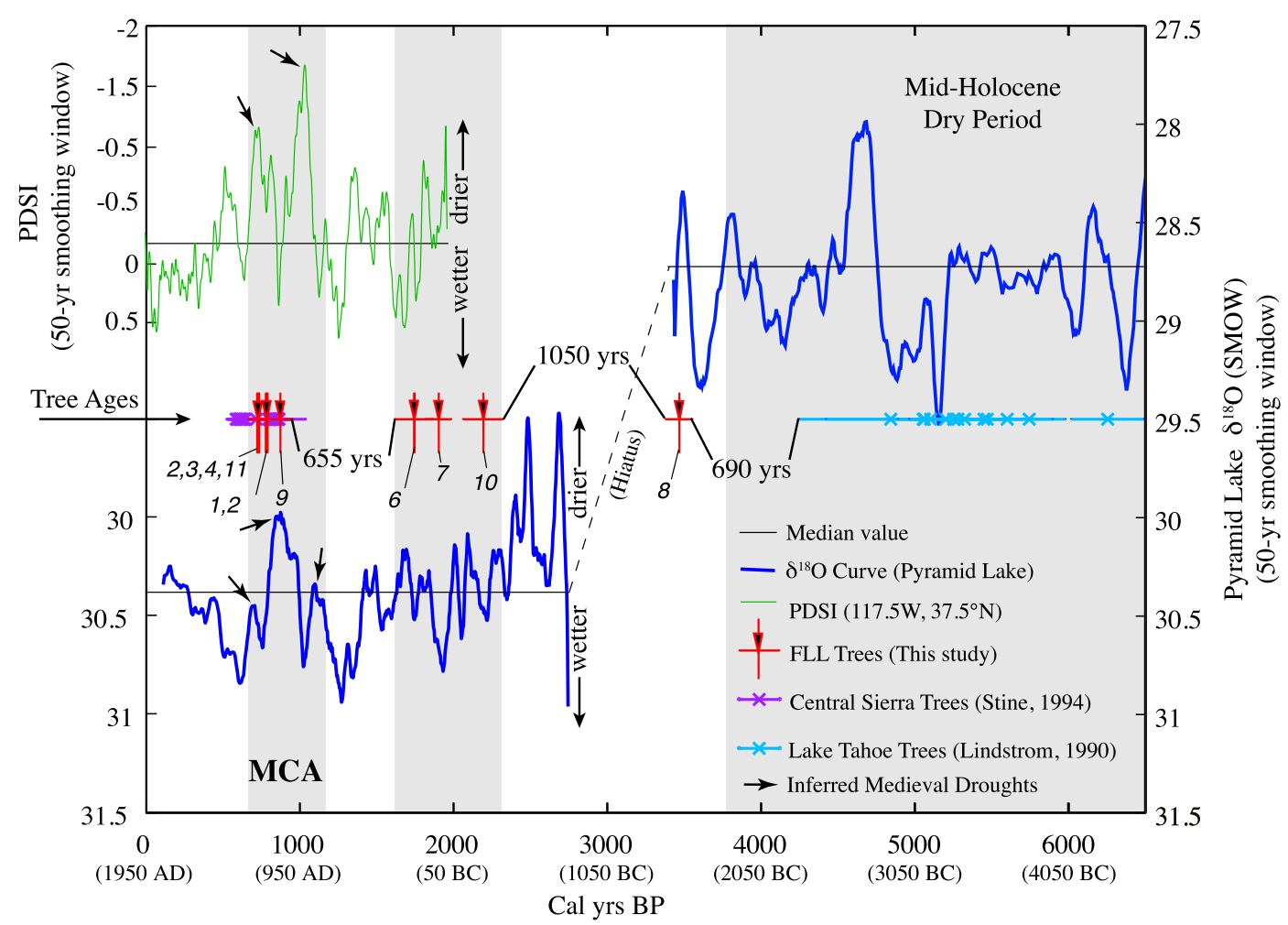

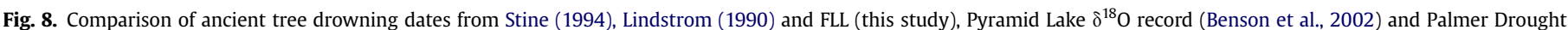

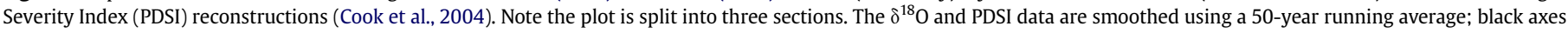

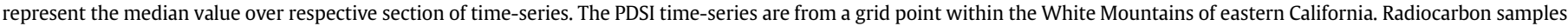

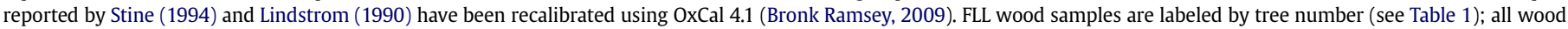

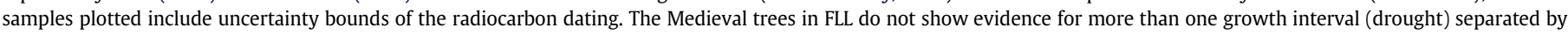

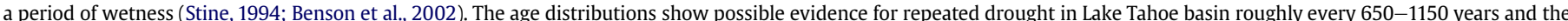

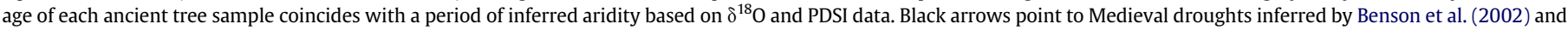
Cook et al. (2004).

relatively quickly and drowned the trees. The same phenomenon occurred in Lake Tahoe, but its shoreline drop during drought was far less because evaporation off the lake was the main cause of shoreline regression. It is important to note geomorphic and stratigraphic relationships (Dingler et al., 2009) suggest that the level of Lake Tahoe has not fallen more than $10 \mathrm{~m}$ for the past several thousand years. The younger age for the Rubicon stump suggests Lake Tahoe Basin may have experienced two intervals of drought during the MCA and contemporaneous trees in Fallen Leaf were not dated by this study. Other explanations are that the Rubicon stump is not presently rooted in situ, or the Lake Tahoe Basin experienced less century-long variability during the MCA than other areas (Stine, 1994; Benson et al., 2002). The overall timing of the MCA observed in FLL tree records ( 800-1300 AD; Fig. 8) is similar to inferred drought observed in the $\delta^{18} \mathrm{O}$ records of Pyramid Lake (Benson et al., 2002) and the North American Palmer Drought Severity Indices reconstructions in the White Mountains and western Great Basin (Cook et al., 2004).

The presence of pre-Medieval aged trees suggest that prolonged drought conditions have existed in the Fallen Leaf watershed at other times during the Holocene and that the older trees have withstood several regression-transgression cycles without falling over. We placed several sections of the Medieval tree \#9 recovered from the lake floor in the open forest to test the ancient wood's resistance to decay. After three years of exposure, the wood remains virtually unaltered by decay and insect attack, while wood samples from dead modern trees show significant signs of such decay. A $1.3 \times 45.7 \mathrm{~cm}$ core sample of tree 9 was examined using a scanning electron microscope. The pores of the wood appear to have accumulated calcite, the highest concentration on the outside perimeter of the tree, decreasing inwards. The calcite is a chemical weathering product derived from the watershed. Perhaps while submerged and under hydrostatic pressure the ancient wood assimilates calcite dissolved in the lake water and that makes the wood more resistant to decay when later exposed during low stands. This topic needs to be investigated further to understand how this process and how wood preserves in alpine lakes.

The branches of the submerged trees are only stubs that protrude from the main trunk. It is interesting to note that by looking at the rings of the branches the branch wood has decomposed at the upper side of the branch. This is confirmed as the rings indicate post mortem decay. The importance of this observation is that there is some mechanism for preferential decay. It is postulated that this decay is caused by the large amount of natural pine pollen that covers the lake each year and slowly settles down onto the upperside of the submerged tree branches much like snow would do in a natural setting. It is further postulated that these pine pollen "snow storms" cover and decay, over the centuries, the submerged brush, grasses, and the other smaller vegetation associated with the area. The large trees that are standing do not accumulate the pollen except for the irregular surfaces on the bark and are hence are less affected.

If we assume each of the standing trees grew in situ during prolonged drought, precipitation must have dropped to or below $60 \%$ normal for at least 100 years during at least three lateHolocene periods (Fig. 8). The drowning-age of trees 6,7 and 10 
roughly match time of a prolonged drought observed in Pyramid Lake (Benson et al., 2002; Mensing et al., 2004) and Mono Lake (Stine, 1990). Tree 8, dated at 1524-1449 BC, approximately corresponds to the termination of middle Holocene aridity documented in many studies throughout the Great Basin (see Benson et al., 2002 and references therein). Several submerged tree stumps in Lake Tahoe are rooted between $1893 \mathrm{~m}$ and $1897 \mathrm{~m}$ (0-3 m below the natural sill) and date between 2300 and 4550 BC (Lindstrom, 1990). Lindstrom (1990) attributes these stumps to a lower shoreline during the mid-Holocene, but others suggest they resulted from tectonic subsidence (Brothers et al., 2009). The West Tahoe Fault defines a massive escarpment in Lake Tahoe, east of Emerald Bay. The 2880-3500 BC tree sampled at the mouth of Emerald Bay is located on the footwall block of the fault and should not be expected to drop during coseismic displacement. Brothers et al. (2009) determined the most recent earthquake on the West Tahoe Fault in Fallen Leaf Lake occurred between 2150 and 2550 BC, slightly younger than the stump ages, but could not rule out that an earlier earthquake may have occurred on a separate fault.

\section{Conclusion}

The submerged Medieval trees and geomorphic evidence for lower shoreline corroborate a prolonged Medieval drought near the headwaters of the Truckee River-Pyramid Lake watershed. Waterbalance calculations independently estimate precipitation to < $60 \%$ normal during Medieval and pre-Medieval megadroughts, and they demonstrate how prolonged changes of Fallen Leaf's shoreline allowed the growth and preservation of Medieval trees far below the modern shoreline. Age groupings of trees may suggest recurring droughts occurred every 600-1050 years during the late Holocene. As additional wood samples are collected in FLL and entered into the tree-ring chronology there is potential to construct a nearly continuous, annually resolved record spanning several millennia. Alpine lakes like Fallen Leaf bounded by glacial till provide hydraulically sensitive environments ideal for studying Holocene climate variations. In central Europe many wood samples from freshwater environments provide tree-ring chronologies spanning the entire Holocene (Nicolussi et al., 2001; Friedrich et al., 2004; Helama et al., 2009). Additional wood samples may help resolve the recurrence intervals, and thus potential causes for severe drought in the northern Sierra Nevada. A systematic sampling of submerged trees in the western USA would extend the late-Holocene paleoclimate record, determine duration and magnitude of multi-centennial drought, and help to answer why such episodes develop and persist.

\section{Acknowledgements}

Support for this work was provided by US Geological Survey/ Desert Research Institute under Project ID\# 2003NV39B, a Geological Society of America graduate research grant and the IRIS undergraduate internship program. F. Biondi was supported, in part by NSF Cooperative Agreement EPS-0814372 to the Nevada System of Higher Education. N. Driscoll was supported in part by a grant from CA DWR. We thank: Glenn Adams, Grant Adams, Bill Craven, John Rich, and Scotty Strachan for their generous help with data acquisition; John Knezovich of Lawrence Livermore National Lab for assistance with the radiocarbon analysis; James Trask and Ivo Bergsohn for helpful discussions regarding the Fallen Leaf Lake water budget; and Scott Cassell and the crew of the Underwater Voyager Project for access to their submersible. Larry Benson, Chris Moy, Phil Caterino, and Susan Lindstrom generously reviewed and helped improve the manuscript.

\section{References}

Adams, K.D., 2003. Age and paleoclimatic significance of late Holocene lakes in the Carson Sink, NV, USA. Quaternary Research 60, 294-306.

Armstrong, C.F., Stidd, C.K., 1967. A moisture-balance profile on the Sierra Nevada. Journal of Hydrology 5, 258-268.

Beaty, R.M., Taylor, A.H., 2009. A 14000 year sedimentary charcoal record of fire from the northern Sierra Nevada, Lake Tahoe Basin, California, USA. Holocene 19, 347-358.

Benson, L., Kashgarian, M., Rye, R., Lund, S., Paillet, F., Smoot, J., Kester, C., Mensing, S., Meko, D., Lindstrom, S., 2002. Holocene multidecadal and multicentennial droughts affecting Northern California and Nevada. Quaternary Science Reviews 21, 659-682.

Bergsohn, I. 2011. Hydro-Geologist South Tahoe Public Utility District, personnal communications.

Biondi, F., Kleppe, J.A., Brothers, D.S., Kent, G.M., 2006. Underwater dendrochronology of the Sierra Nevada: testing the Medieval mega-drought hypothesis. Eos Transactions AGU 87.

Birkeland, P.W., 1964. Pleistocene glaciation of the northern Sierra Nevada, north of Lake Tahoe, California. Journal of Geology 72, 810-826.

Bronk Ramsey, C., 2009. Bayesian analysis of radiocarbon dates. Radiocarbon 51, 337-360.

Brothers, D.S., Kent, G.M., Driscoll, N.W., Smith, S.B., Karlin, R., Dingler, J.A. Harding, A.J., Seitz, G.G., Harding, A.J., 2009. New constraints on deformation, slip rate, and timing of the most recent earthquake on the west Tahoe-Dollar point fault, Lake Tahoe basin, California. Bulletin of the Seismological Society of America 99, 499-519.

Cayan, D.R., Redmond, K.T., Riddle, L.G., 1999. ENSO and hydrologic extremes in the western United States. Journal of Climate 12, 2881-2893.

Cook, E.R., Seager, R., Heim, R.R., Vose, R.S., Herweijer, C., Woodhouse, C., 2010. Megadroughts in North America: placing IPCC projections of hydroclimatic change in a long-term palaeoclimate context. Journal of Quaternary Science 25, 48-61.

Cook, E.R., Woodhouse, C.A., Eakin, C.M., Meko, D.M., Stahle, D.W., 2004. Long-term aridity changes in the western United States. Science 306, 1015-1018.

Danforth, W.W., 1997. Xsonar/ShowImage: a complete System for rapid side-scansonar processing and display. In: U.S. Geological Survey Open-File Report, p. 99.

Dingler, J.A., Kent, G., Driscoll, N., Babcock, J.M., Harding, A.J., Seitz, G.G., Karlin, R. Goldman, C., 2009. A high-resolution seismic CHIRP investigation of active normal faulting across the Lake Tahoe Basin, California-Nevada. Geological Society of America Bulletin 121, 1089-1107.

Freeze, R.A., Cherry, J.A., 1972. Groundwater. Prentice Hall, Inc, Eglewood Cliffs, NJ.

Friedrich, M., Remmele, S., Kromer, B., Hofmann, J., Spurk, M., Kaiser, K., Orcel, C. Kuppers, M., 2004. The 12,460-year Hohenheim oak and pine tree-ring chronology from Central Europe; a unique annual record for radiocarbon calibration and paleoenvironment reconstructions. Radiocarbon 46, 1111-1122.

Graham, N.E., Hughes, M.K., 2007. Reconstructing the Mediaeval low stands of Mono Lake, Sierra Nevada, California, USA. Holocene 17, 1197-1210.

Graham, N.E., Hughes, M.K., Ammann, C.M., Cobb, K.M., Hoerling, M.P., Kennett, D.J., Kennett, J.P., Rein, B., Stott, L., Wigand, P.E., Xu, T.Y., 2007. Tropical Pacific midlatitude teleconnections in medieval times. Climatic Change 83, 241-285.

Graumlich, L.J., 1993. A 1000-year record of temperature and precipitation in the Sierra-Nevada. Quaternary Research 39, 249-255.

Hanes, T., 1981. Hydrologic analysis of the fallen Leaf Lake watershed and operation plan for fallen Leaf lake. In: Lake Tahoe Basin Management Unit Report. U.S. Forest Service South Lake Tahoe.

Helama, S., Merilainen, J., Tuomenvirta, H., 2009. Multicentennial megadrought in northern Europe coincided with a global El Nino-southern Oscillation drought pattern during the medieval climate Anomaly. Geology 37, 175-178.

Hallett, D.J., Anderson, R.S., 2010. Paleofire reconstruction for high-elevation forests in the Sierra Nevada, California, with implications for wildfire synchrony and climate variability in the late Holocene. Quaternary Research 73, 180-190.

Kleppe, J.A., 2005. A study of ancient trees rooted 36.5M (120') below the surface leve of Fallen Leaf Lake. Nevada Water Resources Journal, Lake Tahoe Edition 2, 29-40.

Leydecker, A., Melack, J.M., 1999. Evaporation from snow in the central Sierra Nevada of California. Nordic Hydrology 30, 81-108.

Lindstrom, S.G., 1990. Submerged tree stumps as indicators of mid-Holocene aridity in the Lake Tahoe region. Journal of California and Great Basin Anthropology 12, 146-157.

McCaughey, J., 2005. Pleistocene Glaciation of the Southwest Tahoe Basin. University of Nevada, Reno.

Meko, D.M., Woodhouse, C.A., Baisan, C.A., Knight, T., Lukas, J.J., Hughes, M.K. Salzer, M.W., 2007. Medieval drought in the upper Colorado River basin. Geophysical Research Letters 34.

Mensing, S.A., Benson, L.V., Kashgarian, M., Lund, S., 2004. A Holocene pollen record of persistent droughts from Pyramid Lake, Nevada, USA. Quaternary Research 62, 29-38.

Nicolussi, K., Kaufmann, M., Melvin, T., van der Plicht, J., Schliebling, P., Thurner, A. 2001. A 9111 year long conifer tree-ring chronology for the European Alps: a base for environmental and climatic investigations. The Holocene 19, 909-920.

Pearson, D., a. J., Inc, 1999. Preliminary Report: Profile Gravity Modeling Lake Tahoe Area (South Lake Tahoe)

Redmond, K.T., Koch, R.W., 1991. Surface climate and Streamflow variability in the western United-States and their relationship to large-scale Circulation Indexes. Water Resources Research 27, 2381-2399. 
Reimer, P.J., Baillie, M.G.L., Bard, E., Bayliss, A., Beck, J.W., Blackwell, P.G., Bronk Ramsey, C., Buck, C.E., Burr, G.S., Edwards, R.L., Friedrich, M., Grootes, P.M., Guilderson, T.P., Hajdas, I., Heaton, T.J., Hogg, A.G., Hughen, K.A., Kaiser, K.F., Kromer, B., McCormac, F.G., Manning, S.W., Reimer, R.W., Richards, D.A., Southon, J.R., Talamo, S., Turney, C.S.M., van der Plicht, J., Weyhenmeye, C.E., 2009. Intcal09 and Marine09 radiocarbon age calibration curves, 0-50,000 years Cal Bp. Radiocarbon 51, 1111-1150.

Riverson, J., Barretto, C., Shoemaker, L., Reuter, J., Roberts, D., 2005. Development of the Lake Tahoe watershed model: Lessons Learned through modeling in a Subalpine Environment. In: Impacts of Global Climate Change: Proceedings of World Water and Environmental Resources Congress. ASCE Anchorage, AK, p. 173.

Saucedo, G.J., Little, J.D., Watkins, S.E., Davis, J.R., Mascorro, M.T., Walker, V.D., Ford, E.W., 2005. Geologic map of the Lake Tahoe basin, California and Nevada: California Geological Survey, scale 1:100,000. In: Regional Geologic Map Series (California Geological Survey). California Geological Survey.

Stine, S., 1990. Late Holocene fluctuations of Mono Lake, eastern California. Palaeogeography Palaeoclimatology Palaeoecology 78, 333.

Stine, S., 1994. Extreme and persistent drought in California and Patagonia during medieval time. Nature 369, 546-549.

Stokes, M.A., Smiley, T.L., 1996. An Introduction to Tree-ring Dating. University of Arizona Press, Tucson.

Swetnam, TW. Baisan, C.A. Caprio, A.C. Brown, P.M., Touchan, R., Anderson, R.S Hallett, D.J., 2009. Multi-millenial fire history of the Giant forest, Sequoia National Park, California, USA. Fire Ecology 5, 120-150.
Swetnam, T.W., 1993. Fire history and climate-change in giant sequoia groves. Science 262, 885-889.

Taylor, A.H., Beaty, R.M., 2005. Climatic influences on fire regimes in the northern Sierra Nevada mountains, Lake Tahoe asin, Nevada, USA. Journal of Biogeography $32,425-438$.

Trask, J., 2007. Resolving Hydrologic Water Balances through Novel Error Analysis, with Focus on Inter-annual and Long-term Variability in the Tahoe Basin. University of California, Davis.

Trask, J., Fogg, G., 2008. Tahoe basin precipitation and watershed streamwater outflow: inter-annual variability and explanatory variables. In: 4th Biennial Tahoe Basin Science Conference. Nevada Water Resources Association Incline Village, NV.

Vorster, P.T., 1985. A Water Balance Forecast Model for Mono Lake. U.S. Department of Agriculture, Forest Service Region 5, California. Earth Resources Monograph 10.

Woodhouse, C.A., Meko, D.M., MacDonald, G.M., Stahle, D.W., Cooke, E.R., 2010 A 1,200-year perspective of 21st century drought in southwestern North America. Proceedings of the National Academy of Sciences of the United States of America 107, 21283-21288.

Yuan, F.S., Linsley, B.K. Howe, S.S., Lund, S.P., McGeehin, J.P., 2006. Late Holocene lake-level fluctuations in Walker Lake, Nevada, USA. Palaeogeography Palaeoclimatology Palaeoecology 240, 497-507.

Yuan, F.S, Linsley, B.K, Lund, S.P. McGeehin, J.P. 2004. A 1200 year record of hydrologic variability in the Sierra Nevada from sediments in Walker Lake, Nevada. Geochemistry Geophysics Geosystems 5, 13. 